\title{
Nutritive value, flavonoid content and radical scavenging activity of the truffle (Terfezia boudieri Chatin)
}

\author{
M. Akyüz \\ Department of Biology, Faculty of Arts and Science, Bitlis Eren University, 13000 Bitlis - TURKEY e-mail address: \\ mehmetaky210@hotmail.com\&mehmetaky210@mynet.com
}

\begin{abstract}
:
In this study, the amounts of dry matter, moisture, crude ash, protein, fat and organic matter in $T$. boudieri were determined to be $89.75,10.25,7.80,20.13,3.45$ and $81.95 \%$ of the dry weight, respectively. The contents of mineral were: macronutrients (mg/g, dry wt) K 63.8, Ca 0.27 and $\mathrm{Na} \mathrm{0.2;} \mathrm{micronutrients} \mathrm{(mg/kg,} \mathrm{dry} \mathrm{wt)} \mathrm{Fe} \mathrm{1455.0,}$ $\mathrm{Zn}$ 42.5, Mn 15.8 and $\mathrm{Cu}$ 30.1. Toxic elements such as $\mathrm{Pb}, \mathrm{Ni}, \mathrm{Cd}$ and $\mathrm{Co}$ concentrations were found to be under the detection limit of the used metod. The distribution of fatty acid was found to be $16.13 \% \mathrm{C}_{16: 0}, 0.98 \% \mathrm{C}_{16: 1}$, $2.98 \% \mathrm{C}_{18: 0}, 4.91 \% \mathrm{C}_{18: 1}, 69.74 \% \mathrm{C}_{18: 2}, 4.53 \% \mathrm{C}_{18: 3}$ and $0.72 \% \mathrm{C}_{22: 0}$ of the wet weight. The amounts of myricetin, kaempferol, naringin, naringenin and resveratrol were determined to be 1.75, 0.25, 98.75, 0.25 and $2.25 \mu \mathrm{g} / \mathrm{g}$ of the dry weight, respectively. And also, free radical scavenging activity was understood to be $22.24 \%$.
\end{abstract}

Keywords: DPPH, edible mushroom, fatty acid, flavonoid, nutritive value, T. boudieri

\section{Introduction}

Mushrooms are valuable healthy foods, low in calories, fats, and essential fatty acids, and rich in vegetable proteins, vitamins and minerals. Although edible wild mushrooms are sold in higher prices in markets than that of cultivated mushrooms, consumers still prefer these because of their flavour and texture. These have become increasingly important in our diet due to their nutritional, pharmacological characteristics (Manzi et al., 1999; Riberio et al., 2009; Akyüz and Kırbağ, 2010; Akyüz et al. 2012a) and popular because of its delicious taste.

Truffles are edible hypogeous fruit bodies produced by various genera of fungi belonging to the class Ascomycetes. The hypogeous ascocarps of these fungi are known as truffles. Among these, Terfezia and Tuber are classified as different taxa of the Pezizales (Bejerano et al., 2004). Underground members of the Pezizaceae are well distributed around the globe. The genera Tirmania and Terfezia are monophyletic, and are morphological species which correspond to phylogenetic species. Species grouped under Terfezia clade are found in semi-arid habitats, and have ornamented and spherical spores. These species are adapted to different types of soils which they exploittogether with specific hosts. 
These are not mycorrhizal with trees. Although other factors might have played a role, host specialization and edaphic tolerances might be the main reason for the speciesdiversity (Diez et al., 2002). Terfezia and Tirmania spp. form mycorrhizae mainly on the roots of the Cistaceae family, and different species of the genus Helianthemum (Dexhemier et al., 1985; Fortas et al., 1992), but they have other symbionts as well. This type of mycorrhizal fungus ramifies through the soil, absorbing nitrogen and other minerals, which are transported back to the host plant (Ewaze and Al-Naama, 1989). These plants and their associated fungi may play a major role in the maintenance of Mediterranean shrublands and xerophytic grasslands, and help prevent erosion and desertification (Honrubia et al., 1992).

Pezizales are found in arid and semi-arid zones of Syria, Iraq,Iran, Lebanon, Bahrain, Jordan, Kuwait, Saudi Arabia, Tunisia, Egypt, Algeria, Morocco, Italy, France, Spain and in the Sahara and the Kalahari Deserts (Lawrynowicz et al., 1997; Al-Rahmah et al., 2001; Al-Ruqaie, 2002; Diez et al., 2002; Mandeel and Al-Laith, 2007; Trappe et al., 2008). People in the certain continents are considered as the largest various truffle consumers, and the truffle commodity is regarded as a costly delicacy as stated by Al-Laith (2010). These are also found in Turkey, in simiar zones (Gücin and Dülger, 1997). T. boudieri is seasonal and it is a socio-economically important mushroom in Turkey. It is edible and grown in certain wild regions of the country. It usually appears in the arid and semiarid zones following the rainy season from March to May (Akyüz et al. 2012b).

Our knowledge on the physiology, biochemistry, plant-fungus relations of the hypogeous members of Pezizaceae are fragmentary. General studies on the composition and nutritional value of truffles have been carried out in some countries where they are known and appreciated. T. boudieri is especially appreciated for its culinary value because of its intense aroma . It is especially hard to understand the characteristics of their fatty acid and flavonoid content and their antioxidant activity. Therefore, the aim of this research is to extend our knowledge on the nutritional value of T. boudieri, and also to analyze their fatty acids, flavonoid content and antioxidant activity within Turkey.

\section{Material and Methods}

\subsection{Sample collection}

The mushroom sample used in this study was obtained from the previous work (Akyüz et al. 2012b). A sample of wild fresh Terfezia boudieri Chatin was collected from the vicinity of Kadıköy, Baskil-Elazığ, Turkey (382 26' 541" N, 38 41' 752" E, 700 m, 13.05.2007). These were collected from the area during spring (from March to May). We identifical the location of the truffles from crevices that appear on the surface of the soil above the truffles. The samples were cleaned without washing, cut into slices, dried at room temperature and then stored.

\subsection{Proximate analysis}

The proximate compositions of $T$. boudieri including moisture, dry matter, crude protein, crude fat, crude ash and organic matter, were determined according to AOAC (1990) methods. Total amount of nitrogen (N) was determined by the Kjeldahl method. Crude protein was calculated as $N \times 6.25$. Crude fat was determined by using the soxhlet extraction method both with a solvent and with a total ash incineration at $550^{\circ} \mathrm{C}$. Organic matter was calculated as \% dry matter - ash.

\subsection{Element analysis}

Each mushroom sample air-dried at room temparature was re-dried at $105^{\circ} \mathrm{C}$ overnight and crushed with a mortar and pestle. The digestion of mushroom samples was performed by using a mixture of $\mathrm{HNO}_{3}: \mathrm{H}_{2} \mathrm{SO}_{4}$ : $\mathrm{H}_{2} \mathrm{O}_{2}$ (10:1:1, $12 \mathrm{ml}$ for $1 \mathrm{~g}$ sample) and by heating these at $100^{\circ} \mathrm{C}$ for about $10-15 \mathrm{~min}$. After cooling, 50 $\mathrm{ml}$ deonized water was added and then all was filtered. In order to determine all the materials, all the used 
glasswares were cleared with deonized water. While amounts of $\mathrm{Fe}, \mathrm{Zn}, \mathrm{Mn}, \mathrm{Cu}, \mathrm{Cr}, \mathrm{Cd}, \mathrm{Co}, \mathrm{Ni}$ and $\mathrm{Pb}$ were determined by atomic absorption spectrometer (Perkin-Elmer, 370, The Perkin-Elmer Corporation Norwalk Connecticut, USA), amounts of $\mathrm{K}, \mathrm{Ca}$ and $\mathrm{Na}$ were determined by atomic emission spectrometer (Eppendorf Geratebau, Netheler+HINZ GMBH Hamburg, GERMANY) (AOAC, 1990).

\subsection{Fatty acid analysis}

2 gof fresh mushroom was finely grounded in a mill for fatty acid analyses and then these were extracted with hexane/isopropanol (3:2 v/v) (Hara and Radin, 1978). The lipid extracts were centrifuged at 10.000 $\mathrm{g}$ for 5 minutes and filtered, and then the solvent was removed on a rotary evaporator at $40^{\circ} \mathrm{C}$. The extracted lipids were stored under $-25^{\circ} \mathrm{C}$ until further analysis. Fatty acids in the lipid extracts were converted into methyl esters by using 2\% sulphuric acid (v/v) in methanol (Christie, 1990). The fatty acid methyl esters were extracted with n-hexane. Then the methyl esters were separated and quantified by gas chromatography and flame-ionization detection (Shimadzu GC 17 Ver. 3) which were linked with a glass GC 10 computer software. Chromatography was performed with a capillary column $(25 \mathrm{~m}$ in length and $0.25 \mathrm{~mm}$ in diameter), Permabound 25 (Macherey-Nagel, Germany) and by using nitrogen as a carrier gas (flow rate $0.8 \mathrm{ml} / \mathrm{min}$ ). The temperatures of the column, detector and injection valve were 130-220, 240 and $280^{\circ} \mathrm{C}$, respectively. Identification of the individual methyl esters was performed by frequent comparison with authentic standard mixtures analyzed under the same conditions.

\subsection{Flavonoid analysis and the chromatographic condition}

$2 \mathrm{~g}$ of dry mushroom was homogenized in $5 \mathrm{ml}$ $80 \%$ methanol. Homogenates were centrifuged at $5000 \mathrm{rpm}$ at $+4^{\circ} \mathrm{C}$. After centrifugation, the supernatant was further concentrated by reducedpressure rotary evaporation. Each extract was re-suspended in dimethyl sulphoxide (DMSO) to produce a stock solution. Chromatographic analysis was carried out using a PREVAIL C18 reversedphase column $(15 \times 4.6 \mathrm{~mm}, 5 \mu \mathrm{m}$, USA $)$; the mobile phase was achieved with methanol/water/acetonitrile $(46 / 46 / 8, \mathrm{v} / \mathrm{v} / \mathrm{v})$ containing $1.0 \%$ acetic acid $(\mathrm{Zu}$ et al., 2006). This mobile phase was filtered through a $0.45 \mu \mathrm{m}$ membrane filter (Millipore), then de-aerated ultrasonically prior to use. Catechin (CA), naringin (NA), rutin (RU), resveratrol (RES), myricetin (MYR), morin (MOR), naringenin (NAR), quercetin (QU) and kaempferol (KA) were quantified by DAD separation at $280 \mathrm{~nm}$ for CA and NA, $254 \mathrm{~nm}$ for RU, MYR, MOR and QU, $306 \mathrm{~nm}$ for RES, and $265 \mathrm{~nm}$ for KA. Flow rate and injection volume were $1.0 \mathrm{ml} / \mathrm{min}$ and $10 \mu \mathrm{L}$, respectively. The chromatographic peaks of the extracts were determined by comparing their retention time with the reference standards. Quantification was carried out by the integration of the peak by using the external standard method. All chromatographic operations were carried out at the temperature of $25^{\circ} \mathrm{C}$.

\subsection{Antioxidant assay by DPPH free radical scavenging activity}

The free radical scavenging effect in extracts was assessed by the decoloration of a methanolic solution of DPPH according to the method of Liyana-Pathiranan and Shahidi (2005). A solution of $0.135 \mathrm{mM} \mathrm{DPPH}$ was prepared in methanol and $4.0 \mathrm{ml}$ of this solution was mixed with 50,100 and $250 \mu \mathrm{L}$ of the extract in DMSO. The reacting mixture was left in a dark at room temperature for 30 mins. The absorbance of the mixture was measured spectrophotometrically at 517 $\mathrm{nm}$. Quercetin and resveratrol were used as references. The ability to scavenge DPPH radical was calculated by the following equation:

DPPH free radical scavenging activity $(\%)=($ Abs control - Abs sample) / (Abs control) $\times 100$ where Abs control is the absorbance of DPPH radical + methanol; Abs sample is the absorbance of DPPH radical + sample extract / standard. 
Table 1. Nutrient contents of T. boudieri in Turkey (\%, dry wt)

\begin{tabular}{|c|c|c|c|c|c|c|c|}
\hline \multicolumn{6}{|c|}{ Nutrient Contents (\%, dry wt) } & \multirow[b]{2}{*}{ Species } & \multirow[b]{2}{*}{ References } \\
\hline Dry Matter & Moisture & $\begin{array}{l}\text { Crude } \\
\text { Ash }\end{array}$ & $\begin{array}{l}\text { Crude } \\
\text { Protein }\end{array}$ & Crude Fat & $\begin{array}{l}\text { Organic } \\
\text { Matter }\end{array}$ & & \\
\hline $89.75 \pm 0.07$ & $10.25 \pm 0.14$ & $7.80 \pm 0.12$ & $20.13 \pm 0.35$ & $3.45 \pm 0.03$ & $81.95 \pm 0.07$ & T. boudieri & In this study \\
\hline $93.67-93.96$ & $6.04-6.33$ & $4.57-8.98$ & $12.3-12.4$ & $5.00-5.54$ & $93.67-93.96$ & T. boudieri & Yildiz et al. (2006) \\
\hline- & - & 12.88 & 17.19 & 6.40 & - & T. claveryi & Ahmed et al. (1981) \\
\hline \multirow[t]{2}{*}{ - } & - & 4.6 & 19.6 & 2.8 & - & T. claveryi & Sawaya et al. (1985) \\
\hline & & 5.4 & 27.2 & 7.4 & & T. nivea & \\
\hline \multirow[t]{2}{*}{-} & - & 5.8 & 17.6 & - & - & T. claveryi & Kaisey et al. (1996) \\
\hline & & 6.9 & 19.2 & & & T. hafizi & \\
\hline \multirow[t]{2}{*}{-} & - & 4.25 & 15.95 & 6.95 & - & T. claveryi & Murcia et al. (2003) \\
\hline & & 8.2 & 22.5 & 19.9 & & P. juniperi & \\
\hline \multirow[t]{2}{*}{-} & - & 1.15 & 11.9 & 0.89 & - & T. claveryi & Al-Ruqaie (2002) \\
\hline & & 1.30 & 6.58 & 1.10 & & T. nivea & \\
\hline \multirow[t]{2}{*}{-} & - & - & $12.82-17.19$ & - & - & T. boudieri & Ibrahim \& Saeed \\
\hline & & & 16.30 & & & T. nivea & (1994) \\
\hline \multirow[t]{3}{*}{ - } & - & 5.90 & 8.02 & - & - & T. claveryi & Al-Naama et al.(1988) \\
\hline & & 4.90 & 13.84 & & & T. nivea & \\
\hline & & 5.60 & 10.49 & & & T. pinoyi & \\
\hline
\end{tabular}

Each value is expressed as mean $\pm \mathrm{SD}$ of three replicate analyses $(\mathrm{n}=3)$.

Table 2. Mineral element concentration of T. boudieri in Turkey (dry wt)

\begin{tabular}{|c|c|c|c|c|c|c|c|c|c|c|c|c|}
\hline \multicolumn{3}{|c|}{ Macro elements } & \multicolumn{8}{|c|}{ Micro elements } & \multirow[b]{2}{*}{ Species } & \multirow[b]{2}{*}{ References } \\
\hline $\begin{array}{l}\mathrm{K} \\
(\mathrm{mg} / \mathrm{g})\end{array}$ & $\begin{array}{l}\mathrm{Ca} \\
(\mathrm{mg} / \mathrm{g})\end{array}$ & $\begin{array}{l}\mathrm{Na} \\
(\mathrm{mg} / \mathrm{kg})\end{array}$ & $\begin{array}{l}\mathrm{Fe} \\
(\mathrm{mg} / \mathrm{kg})\end{array}$ & $\begin{array}{l}\mathrm{Zn} \\
(\mathrm{mg} / \mathrm{kg})\end{array}$ & $\begin{array}{l}\mathrm{Mn} \\
(\mathrm{mg} / \mathrm{kg})\end{array}$ & $\begin{array}{l}\mathrm{Cu} \\
(\mathrm{mg} / \mathrm{kg})\end{array}$ & $\begin{array}{l}\mathrm{Pb} \\
(\mathrm{mg} / \mathrm{kg})\end{array}$ & $\begin{array}{l}\text { Co } \\
(\mathrm{mg} / \mathrm{kg})\end{array}$ & $\begin{array}{l}\mathrm{Ni} \\
(\mathrm{mg} / \mathrm{kg})\end{array}$ & $\begin{array}{l}\mathrm{Cd} \\
(\mathrm{mg} / \mathrm{kg})\end{array}$ & & \\
\hline $63.8 \pm 1.7$ & $0.27 \pm 0.02$ & $207.5 \pm 5.6$ & $1455.0 \pm 9.5$ & $42.5 \pm 2.1$ & $15.8 \pm 1.2$ & $30.1 \pm 1.2$ & & - & - & - & T. boudieri & In this study \\
\hline 9.96 & 0.68 & 290.00 & 170.00 & 130.00 & 22.00 & 83.00 & - & - & - & - & T. claveryi & Ahmed et al. (1981) \\
\hline 10.30 & 1.00 & 1.11 & 0.33 & 0.03 & 0.01 & 0.03 & $<0.005$ & - & 0.002 & $<0.001$ & T. boudieri & Yildiz et al. (2006) \\
\hline
\end{tabular}

$\mathrm{Pb}, \mathrm{Co}, \mathrm{Ni}$ and $\mathrm{Cd}$ : analysized, but not detected (the concentrations were under the detection limit of the metod used). The limits are 5-25, 1-5, 1-5 and 0.4-2 mg/g, respectively, Each value is expressed as mean $\pm \mathrm{SD}$ of three replicate analyses $(\mathrm{n}=3$ ) 


\subsection{Statistical analysis}

Experimental values were given as means \pm standard deviation (SD). Statistical significance wasdetermined by one-way variance analysis (ANOVA). Mean values were found with SPSS 13.0 (SPSS, Chicago, Illinois, USA). Each experiment was repeated three times and the results were reached by calculating the average value for three experiments.

\section{Results and Discussion}

\subsection{Nutrient Composition}

Dry matter and moisture content were $89.75 \%$ and $10.25 \%$, respectively (Table 1 ). With respect to the dry matter and moisture contents, Yildiz et al., (2006) obtained $93.67-93.96 \%$ and $6.04-6.33 \%$ in $T$. boudieri, respectively (Table 1). Therefore, the dry matter content was low, but moisture content was higher than the previously reported.

Ash content (7.80\%) determined was lower than reported earlier by Ahmed et al. (1981), Murcia et al. (2003), Yildiz et al. (2006), and higher than previously reported by Sawaya et al. (1985), Al-Naama et al. (1988), Kaisey et al. (1996), Al-Ruqaie (2002), Murcia et al. (2003), and Yildiz et al. (2006) see Table 1.

The content of crude fat was found to be $3.45 \%$ in $T$. boudieri (Table 1). The crude fat contents reported earlier were $0.89-19.9 \%$ in different truffles such as Terfezias pp., Tirmania spp. and Picoa juniperi (Ahmed et al., 1981; Sawaya et al., 1985; Al-Ruqaie, 2002; Murcia et al., 2003; Yildiz et al., 2006) see Table 1. These results were different from the results of present work as seen in Table 1.

The protein concentrations of the studied legume seeds show that these can contribute to the daily protein need of $23.6 \mathrm{~g} / 100 \mathrm{~g}$ for adults as recommended by the National Research Council (1974). The crude protein content $(20.13 \%)$ determined was lower than what was reported earlier by Sawaya et al., (1985) and Murcia et al., (2003), but higher than what was previously reported by Ahmed et al. (1981), Al-Naama et al. (1998), Ibrahim and Saeed (1994), Kaisey et al. (1996), Al-Ruqaie (2002), Murcia et al., (2003), Yildiz et al. (2006). This difference was probably due to the analysis of mushroom samples being obtained from different regions (Table 1).

\subsection{Mineral element contents}

As seen in Table 2, the macro element data were different from the the data obtained in the present study (Ahmed et al. 1981; Yildiz et al. 2006). The high quantity of potassium, magnesium and calcium together with the high quantity of sodium, plus the essential elements like iron, manganese, zinc and copper allow us to consider these as an excellent source of bioelements. As stated by previous researchers, mushrooms are recommended to be used in the preparation of diets for individuals who have low levels of these mineral elements (Manzi et al., 1999; Riberio et al., 2009; Akyüz and Kırbağ, 2010). Although the mineral elements form a small proportion of the total composition of total body weight although they do not contribute to the energy value of the food, these are of great physiological importance particularly to the body metabolism. Furthermore, the microelement contents of $T$. boudieri found in present study were changeable to other investigation (Ahmed et al. 1981; Yildiz et al. 2006) shown in Table 2. The amount of soil element is directly related to the mineral element levels of the mushroom. Normally, the changes in mushroom's element levels are closely based on the relationship between mycorrhizal plant and the soil. While mushroom mycelium provides the necessary minerals for the plant, it also gets the item sit needs from the plant.

Toxic metals such as lead, cobalt, nickel and cadmium were also tried to be analysed in this work, but concentrations were under the detection limit of the used metod (see Table 2). 
Table 3. Fatty acids composition of $T$. boudieri in Turkey (\%, wet wt)

\begin{tabular}{|c|c|c|c|c|c|c|c|c|c|c|c|c|c|c|c|c|c|c|}
\hline \multicolumn{17}{|c|}{ Fatty acids (\%) } & \multirow[b]{2}{*}{ Species } & \multirow[b]{2}{*}{ References } \\
\hline $\mathrm{C}_{10: 0}$ & $\mathrm{C}_{14: 0}$ & $\mathrm{C}_{15: 0}$ & $\mathrm{C}_{16: 0}$ & $\mathrm{C}_{16: \ln 9}$ & $\mathrm{C}_{17: 0}$ & $\mathrm{C}_{18: 0}$ & $\mathrm{C}_{18: \ln 9}$ & $\mathrm{C}_{18: 2 \mathrm{n} 6}$ & $\mathrm{C}_{18: 3 \mathrm{n} 6}$ & $\mathrm{C}_{20: 0}$ & $\mathrm{C}_{20: 2}$ & $\mathrm{C}_{21: 0}$ & $\mathrm{C}_{21: 0}$ & $\mathrm{C}_{22: 0}$ & $\mathrm{C}_{22: 1}$ & $\mathrm{C}_{24: 0}$ & & \\
\hline - & - & - & 16.13 & 0.98 & - & 2.98 & 4.91 & 69.74 & 4.53 & - & - & - & - & 0.72 & - & - & T. boudieri & In this study \\
\hline \multirow[t]{2}{*}{ - } & 2.1 & 1.3 & 17.0 & 1.4 & 1.4 & 4.5 & 6.9 & 45.4 & 5.8 & 3.7 & - & - & 0.4 & 4.0 & 1.9 & 3.9 & T. claveryi & Murcia et al. (2003) \\
\hline & 1.2 & 0.4 & 8.0 & 2.5 & 0.9 & 2.2 & 23.5 & 53.0 & 2.1 & 2.1 & & & - & 0.8 & 2.0 & 1.5 & P. juniperi & \\
\hline \multirow[t]{2}{*}{ - } & 2.1 & - & 23.5 & & - & 12.2 & - & 62.2 & & - & - & - & - & - & - & - & T. claveryi & Kaisey et al. (1996) \\
\hline & 0.7 & & 24.0 & & & 14.8 & & 60.5 & & & & & & & & & T. hafizi & \\
\hline 10.37 & - & - & 23.7 & 1.295 & - & 3.990 & 10.37 & 44.35 & 2.120 & - & 1.635 & 1.02 & - & - & - & - & T. boudieri & Yildiz et al. (2006) \\
\hline- & $2.6-6.3$ & - & $\begin{array}{l}11.7- \\
18.9\end{array}$ & & - & $3.3-6.2$ & $\begin{array}{l}3.8- \\
23.1\end{array}$ & $\begin{array}{l}47.9- \\
70.5\end{array}$ & $0.9-2.4$ & - & - & - & - & - & - & - & T. melanosporum & Harki et al. (2006) \\
\hline
\end{tabular}

(C16:0) palmitic acid; (C16:1) palmitoleic acid; (C18:0) stearic acid; (C18:1) oleic acid;(C18:2) linoleic acid; (C18:3) linolenic acid; (C22:0) behenic acid

\subsection{Fatty acid composition}

The present study describes the presence of various fatty acids in T. boudieri see Table 3 . The fatty acids compositions showed high quantities of linoleic acid $\left(69.74 \% \mathrm{C}_{18: 2}\right)$, which was followed by palmitic acid $\left(\mathrm{C}_{16: 0}\right)$, oleic $\left(\mathrm{C}_{18: 1}\right)$ and linolenic acid $\left(\mathrm{C}_{18: 3}\right)$ as seen in Table 3. It seems that the quantity of linoleic acid is higher than that reported previously, but other fatty acid values are different than those reported by other researchers (Kaisey et al., 1996; Murcia et al., 2003; Harki et al., 2006; Yildiz et al., 2006) shown in Table 3. Large quantitative differences, probably due to the heterogeneity of the samples analysed, were reported by Harki et al. (2006). Unsaturated fatty acid predominated over saturated fatty acid in all the studied mushrooms, which is consistent with other studies (Riberio et al., 2009). Oleic acid is known to help the frequency of cardiovascular diseases to decrease and known for its effectiveness in reducing cholesterol levels (Tomas et al., 2001; Puiggros et al., 2002; Pacheco et al., 2008). Linoleic acid is an essential fatty acid which cannot be synthesized by the human organism, due to the lack of desaturase enzymes required for its production. Linolenic acid is an essential fatty acid which is able to produce the omega-3 fatty acids series in human bodies, including eicosapentaenoic acid and docosahexaenoic acid.
The omega-3 and -6 fatty acids are biosynthetic precursors of eicosanoids, meaning that their intake concentrations will strongly affect eicosanoids production, and, therefore, the organism's metabolic functions (Voet and Voet, 2004). Besides these, various studies have show that these can also decrease the total amount of fat in blood (cholesterol), and reduce the risk of cardiovascular diseases. A deficient intake of essential fatty acids can cause many problems, such as dermatitis, imunosupression and cardiac disfunctions as stated by Burtis and Ashwood (1996).

\subsection{Flavonoid contents and DPPH free radical scavenging activity}

The amounts of myricetin, kaempferol, naringin, naringenin and resveratrol consisted 1.75, 0.25, $98.75,0.25$ and $2.25 \mu \mathrm{g} / \mathrm{g}$ of the dry weight, respectively. Naringin content $(98.75 \mu \mathrm{g} / \mathrm{g})$ was very high, whereas kaempferol and naringenin contents were very low in T. boudieri (see in Table 4). Furthermore; rutin, morin, quercetin and catechin were not detected in $T$. boudieri (see Table 4). For humans, several health beneficial properties of dietary flavonoids are recognized for their antioxidant and antiproliferative effects which may protect the body from various diseases, such as cancers, cardiovascular disease and inflammatory (Middleton et al. 2000; Nijveldt et al. 
Table 4. Flavonoid contents ( $\mu \mathrm{g} / \mathrm{g}$, dry wt) and free radical scavenging activity of $T$. boudieri in Turkey

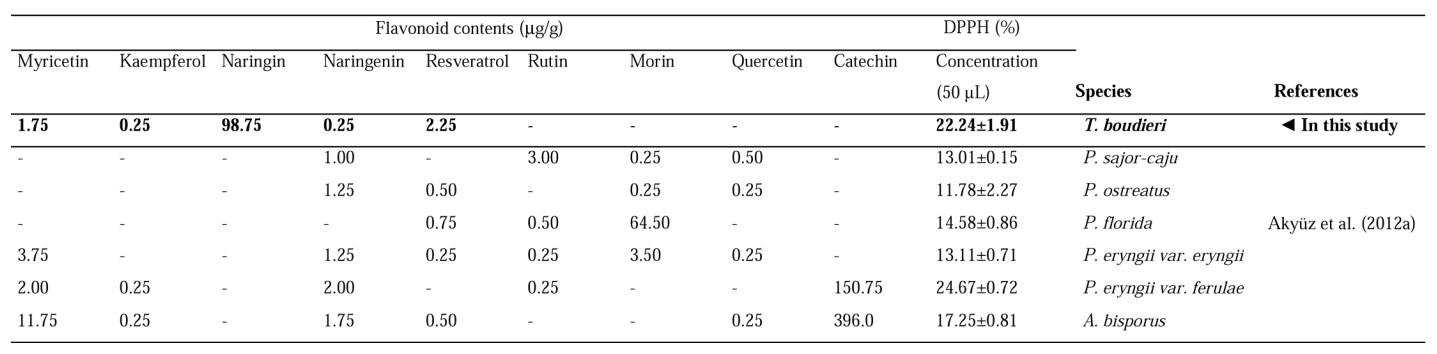

2001). Upto our knowledge, in the literature, there is no study on the flavonoid of studied mushroom species. When compared with different mushroom species, it has been concluded that the types and the amounts of the flavonoids change see Table 4. And also, free radical scavenging activity was $22.24 \%$ (Table 4). The inhibition percent of DPPH quenching of the dried truffles ranged between 24.5 and $69.2 \%$ with an average of $30.6 \%$ (Al-Laith, 2010). Furthermore, the observed high correlation between the various assays employed and phenolic contents is a strong indication that these phenolics (total, free and flavonoids) are among the main sources of antioxidant activity in desert truffles as stated by AlLaith (2010). It seems that the radical scanvenging activity of $T$. boudieri might be different than what was expressed in an earlier published report (Akyüz et al. 2012b). Flavonoid contents and antioxidant activity of mushrooms depend on its relation with the strain/type, the ascocarp size, harvest time, host plant, and the ecocystems. Thus, it is expected that truffles originating from different geographical origins can show some variations. Furthermore, it is also expected that the antioxidant attributes of the truffles may be affected by the nature and by the extent of association with its host root associate Helianthemum spp. as stated by Al-Laith (2010). In conclusion, it has been determined that T. boudieri is rich from the point of view of unsaturated fatty acids such as linoleic, oleic and palmitic acid, and especially flavonoid such as myricetin, kaempferol, naringin, naringenin and resveratrol.

\section{References}

Ahmed, A.A., Mohamed, M.A., Hami, M.A. 1981. Libyan truffles Terfezia boudieri Chatin chemical composition and Toxicity. J. Food Sci. 46, 927-929.

Akyüz, M., Kırbağ, S. 2010. Nutritive value of wild edible and cultured mushrooms. Turk. J. Biol. 34, 97-102.

Akyüz, M., Onganer, AN, Erecevit P., Kirbag, S. 2012a. Flavonoid contents and 2,2-diphenyl-1picrylhydrazyl radical scavenging activity of some edible mushrooms from Turkey: A. bisporus and Pleurotus spp. Curr. Top. Nutraceut. R. 10, 133136.

Akyüz, M., Kırbag, S., Kurşat, M., 2012b. Ecological aspects of the arid and semi-arid truffle in Turkey: evaluation of soil characteristics, morphology, distribution, and mycorrhizal relationships. Turk. J. Bot. 36, 386-391.

Al-Laith, A.A.A. 2010. Antioxidant components and antioxidant/antiradical activities of desert truffle 
(Tirmania nivea) from various Middle Eastern origins. J. Food Compos. Anal. 23, 15-22.

Al-Naama, M.M., Ewaze, J.O., Nema, J.H. 1998. Chemical constituents of Iraqi truffles. Iraq J. Agric. Sci. 6, 1-56.

Al-Rahmah, A.N. 2001. Truffle of deserts and jungles. King Saud University Publication Riyadh, Saudi Arabia, 272 p.

Al-Ruqaie, I.M. 2002. Effect of different treatment processes and preservation methods on the quality of truffles. I. Conventional methods. Pak. J. Biol. Sci. 5, 1088-1093.

AOAC, 1990. Official Methods of Analysis of Association of the Official Analytical Chemists. In: Helrich K (ed.), Fiftheet edition. Published by the Association of Official Analytical Chemists Inc. Wilson Boulevard Ailington Virginia 22201 USA, 1213, ISBN: 0-995584-42-0, ISSN: 0066-961X.

Bejerano, N.R., Li, Y.F., Kagan, V. 2004. Homokaryotic and heterokaryotic hyphae in Terfezia. Anton. Leeuw. 85, 165-168.

Burtis, C.A., Ashwood, E.R. 1996. Tietz fundamentals of clinical chemistry. WB Saunders Company, Philadelphia.

Christie, W.W. 1990. Gas chromatography and lipids. The oily press, Glaskow, UK, 573-577 pp.

Diez, J., Manjon, J.L., Martin, F. 2002. Molecular phylogeny of the mycorrhizal desert truffles (Terfezia and Tirmania), host specificity and edaphic tolerance. Mycologia 94, 247-259.

Dexhemier, J., Gerard, J., Leduc, J.P., Chevalier, G. 1985. Comparative ultrastructural study of symbiotic mycorrhizal associations between Helianthemumsalicifolium-Terfezia claveryi and Helianthemum salicifolium-Terfezia leptoderma. Can. J. Bot. 63, 582-591.
Ewaze, J.O., Al-Naama, M.M. 1989. Studies on nitrogen metabolism of Terfezia spp. and Tirmania spp. New Phytol. 112, 419-422.

Fortas, Z., Chevalier, G. 1992. Effet des conditions de culturesur la mycorhization de Helianthemum guttatum partrois especes de terfez des genres Terfezia et Tirmania de Algerie. Can. J. Bot. 70, 2453-2460.

Gücin, F., Dülger, B. 1997. The researchers on the keme truffle- Terfezia boudieri Chatin that is edible and showing antimicrobial activities. Ekoloji. 23, 27-33.

Hara, A., Radin, N.S. 1978. Lipid extraction of tissues with a low-toxicity solvent. Anal. Biochem. 90, 420-426.

Harki, E., Bouya, D., Dargent, R. 2006. Maturationassociated alterations of the biochemical characteristics of the black truffle Tuber melanosporum Vitt. Food Chem. 99, 394-400.

Honrubia, M., Cano, A., Molina-Ninirola, C. 1992. Hypogeous fungi from southern Spanish semi-arid lands. Persoonia 14, 647-653.

Ibrahim, NA., Saeed AA. 1994. Protein content and amino acid analysis of the desert truffles. Ann. Agr. Sci. Moshtohor 32, 1569-1573.

Kaisey, M.T., Hadwan, H.A., Abeed, H.A., Taher E.J., Dhar, B.L. 1996. Proximate analysis of Iraqi truffles. Mush. Res. 5, 105-108.

Ławrynowicz, M., Marković, M., Milenković, M., Ivancevic B. 1997. Terfezia terfezioidesa new hypogeous fungus for Balkan Peninsula. Acta Mycol. 32, 233-238.

Liyana-Pathiranan, C.M., Shahidi, F. 2005. Antioxidant activity of commercial soft and hard wheat (Triticum aestivum $\mathrm{L}$.) as affected by gastric $\mathrm{pH}$ conditions. J. Agric. Food Chem. 53, 2433-2440. 
Mandeel, Q.A., Al-Laith, A.A.A. 2007. Ethnomycological aspects of the desert truffle among native Bahraini and non-Bahraini peoples of the Kingdom of Bahrain. J. Ethnopharm. 110, 118-129.

Manzi, P., Gambelli, L., Marconi S., 1999. Nutrients in edible mushrooms: an inter species comparative study. Food Chem. 65, 477-482.

Middleton, E. Jr., Kandaswami, C., Theoharides, TC., 2000. The effects of plant flavonoids on mammalian cells: Implications for inflammation, heart disease, and cancer. Pharmacol Rev. 52, 67751.

Murcia, M.A., Martinez-Tome, M., Vera, A.M., Morte, A., Gutierrez, A., Honrubia, M., Jimenez, A.M. 2003. Effect of industrial processing on desert truffles (Terfezia claveryi Chatin and Picoa juniperi Vittadini): proximate composition and fatty acids. J. Sci. Food Agric. 83, 535-541.

Nijveldt, R.J., Van Nood, E., Van Hoorn, D.E., Boelens, P.G., Van Norren, K., Van Leeuwen, P.A. 2001. Flavonoids: a review of probable mechanisms of action and potential applications. Am. J. Clin. Nutr., 74, 418-425.

National Research Council, 1974. Recommended daily dietary allowance. Nutr. Rev. 31, 373-395.

Pacheco, Y.M., López, S., Bermúdez, B., Abia, R., Villar, J., Muriana, F.J.G. 2008. A meal rich in oleic acid beneficially modulates postprandial sICAM-1 and SVCAM-1 in normotensive and hypertensive hypertriglyceridemic subjects. J. Nutr. Biochem. 19, 200-205.

Puiggrós, C., Chacón, P., Armadans, L.I., Clapes, J. , Planas, M. 2002. Effects of oleic-rich and omega 3-rich diets on serum lipid pattern and lipid oxidation in mildly hypercholesterolemic patients. Clin. Nutr. 21, 79-87.
Riberio, B., Guedes de Pinho, P.,Andrade, P.B., Baptista, P., Valentao, P. 2009. Fatty acid composition of wild edible mushrooms: A comparative study. Microchem. J. 93, 29-35.

Sawaya, W.N., Al-Shalhat, A., Al-Sogair, A., AlMohammad, M. 1985. Chemical composition and nutritive value of truffles of Saudi Arabia. J. Food Sci. 50, 450-453.

Tomás, M., Sentí, M., Elosua, R., Vila, J., Sala, J., Masia R., Marrugat J. 2001. Interaction between the Gln-Arg 192 variants of the paraoxonase gene and oleic acid intake as a determinant of highdensity lipoprotein cholesterol and paraoxonase activity. Eur. J. Pharm. 432, 121-128.

Trappe, J.M., Claridge, A.W., Arora, D., Smit, W.A. 2008. Desert truffles of the African Kalahari: ecology, ethnomycology, and taxonomy. Econ. Bot. 62, 521-529.

Voet, D., Voet, J.G., 2004. Biochemistry (3rd ed). Hoboken NJ, John Wiley \& Sons.

Yildiz, A., Dündar, A., Acay, H., Akyüz, M., Yeşil, Ö.F. 2006. Nutritive value of Pleurotus eryngii and Terfezia boudieri. The Scientific and Technological Research Council of Turkey, Agriculture, Forestry and Veterinary Sciences Research Grant Group (TOVAG), Project No: TUBITAK-TOVAG-1040108, 43 pp.

Zu, Y.G., Li, C.Y., Fu, Y.J., Zhao, C. 2006. Simultaneous determination of catechin, rutin, quercetin kaempferol and isorhamnetin in the extract of sea buckthorn (Hippophae hamnoides L.) leaves by RP-HPLC with DAD. J.Pharm. Biomed. Anal. 41, 714-719. 